\title{
Changing Demographics and the Challenges to Indian Retailers
}

\author{
${ }^{1}$ CMA JayashreeRamanan, ${ }^{2}$ Dr. K.P.V. Ramanakumar \\ ${ }^{1}$ Research Scholar, SCSVMV University, Kanchipuram, Tamil Nadu, India \\ ${ }^{2}$ Dean, Dept. of Mgt. Studies, SCSVMV University, Kanchipuram, Tamil Nadu, India
}

\begin{abstract}
The generation a consumer was born into, defines their attitudes and experiences, which plays a great role in their buying behaviour. Although individuals have distinct characteristics, researchers are trying to identify commonbehaviours and attitudes within the generational groups. The main objective of this paper is to understand and highlight the challenges created by demographic trends to the Indian retailers. Population dynamics have always been constantly changing and the world's population is expected to cross 9 billion by 2050. This paper analyses the enormous challenges to the retailers posed by changing demographics and how they need to be prepared to face them and to convert them into business opportunities.
\end{abstract}

Key words: Demography, consumer, Indian retailer, challenges, opportunities

\section{Introduction}

Demography is the study of population size, growth and age structure and the forces that lead to population change namely, fertility, mortality, migration etc. The world's population has risen from two billion in 1930 to around seven billion currently. It is expected to grow to 9 billion by 2050 and to 14 billion by 2100. The population in India is 1.21 billion(2011 census) and is expected to grow to 1.6 billion by 2050 . By 2050 , it has been estimated that $86 \%$ of the world population will be in less developed countries. The majority of the future population growth is likely to occur in cities especially in Asia, Africa and Latin America. It has been estimated that over $60 \%$ of the world population will be in urban areas within the next 25 years. India has more than $50 \%$ of its population below the age of 25 and more than $65 \%$ below the age of 35 . The average age of an Indian is expected to be 29 by 2020 .

\section{Objective of the study and Methodology}

The objective of the study is to analyse the demographic changes and the changing consumer base and its impact on the Indian retailer. This paper is based on case studies, statistical data, analytical and logical understanding of various journals, research papers, books, newspaper and the internet.

The population growth consists of

\section{Population Growth}

a. Growing population

b. Ageing populations.

Growing population is characterised by higher disposable income, nuclear families, urbanisation, migration to off-shore due to globalisation and opportunities in MNCs, life style changes etc.

Whereas the ageing population is characterised by higher share of elderly people, increased life expectancy due to advancements in health care and treatment. In retail, consumer is the king. To stay in the business, the retailers need to be proactive and watch the trends and address the challenges. These demographic shifts will create a generation starved of time but money rich. The consumers will demand quality products and service, hassle free procurement and use and the market would be ruled only bythe consumers.

According to WHO, 2 billion people will be at least 60 years old by 2050 , presenting a great opportunity for retailers to take stock of the segment's particular needs. Opportunities include providing electronic shopping carts and online delivery options.

According to Nielson Global Survey, "The Age Gap", there are significant gaps between the products and services available and what consumers say that they need for their health and well- being during the twilight years.In-store amenities like ample lighting, wider aisles, easy -to -read and easy- to- open product packaging and transportation are what they look for.

As far as the product is concerned, catering to the special nutritional needs of seniors, offering in small packages, door delivery, after-sales service are the major challenges for manufacturers as well as retailers. 
Top six concerns about life in old age

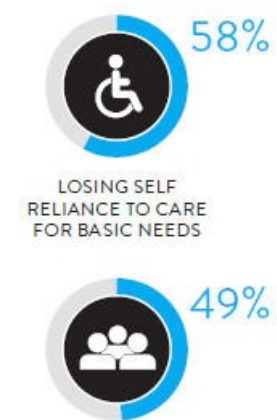

BEING A BURDEN ON FAMILYMEMBERS OR FRIENDS
GLOBAL AVERAGE

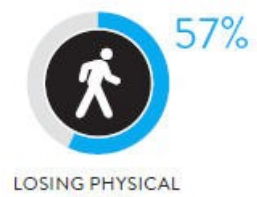

AGILITY

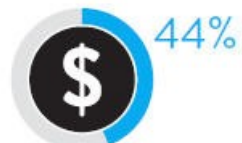

HAVING ENOUGH MONEY TO LIVE

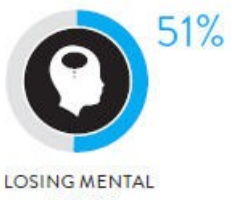
AGILITY

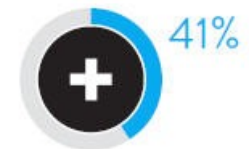

HAVING ENOUGH MONEY TO COVER

Source: Nielsen - The Age Gap 25 ${ }^{\text {th }}$ February 2014

It is for the retailers and the manufacturers to understand the needs of the changing demographics and convert them into opportunities so that they not only continue to stay in business but also areon the growth path.

\section{Classification of Indian Households :}

According to the Mckinsey Global Institute report May 2007 “The bird of Gold: The rise of India's consumer market", Indian households have been classified into five groups based on annual disposable income:

They are

- Globals: having an annual disposable income of over Rs. 1 million. This constitutes the richest people in the country and can afford a luxurious lifestyle. Politicians, large business owners, Senior executives of corporates belong to this category.

- Strivers: Their annual disposable income is between Rs. 5,00,000 to Rs. 1 million p.a. per household. This group consists of successful people in cities, professionals, businessmen and people in villages having established sources of income and substantial savings.

- Seekers: Their disposable income falls in the range of Rs. 2,00,000 to Rs. 5,00,000 per annum per household. This group consists of white-collar employees, mid-level government officials, medium scale businessmen and those fresh from colleges.

- Aspirers: Their disposable income falls between Rs. 90,000 and Rs. 2,00,000 p.a. per household. This group consists of small shop keepers and farmers and low skilled workers in industries and services. These people spend nearly $50 \%$ of their income in satisfying their basic needs.

- Deprived: This group consists of people whose annual disposable income is less than Rs. 90,000 p.a. per household. They are the poorest in the country and meet both ends by doing highly unskilled or lowskilled jobs. They find it really hard to eke out a living.

The top three segments- globals, strivers and seekers, comprising 14 million households in 2006 are existing and potential shoppers for organised retail. Only these income groups have the income to spend on categories beyond the basic necessities. The top 1 million households are 'globals' and are global trotters. They have the luxury of vacations abroad and can spend on what they want and are highly demanding.

The next 13 million belonging to "Seekers" and "Strivers" categories are a great potential to the retail market. They are experimenting on new formats, categories.

The 91 million "Aspirer" category are starting to buy more than the basics but are still not comfortable with organized retail. Currently, they spend beyond basics during special occasions like weddings and other functions. As their income increases, it is likely that they visit the stores in the malls.

The bottom 101 million households spend only on necessities. They are unlikely to be users of organised retail in the near future say, 5 to 10 years. However, this is a great opportunity for the unorganized retail. 


\section{Overview of Indian retail}

India's retail market is expected to cross 1.3 trillion USD by 2020 as per the PWC retail report 2014. The modern retail is expected to grow to 220 billion USD by 2020 , which has a great potential for growth across various segments. By 2020, there will be nearly 200 cities in India with a population of more than 0.5 million which will drive modern retail growth. India's retail is one of the most challenging, dynamic and exciting markets to operate in. Hence most global retailers are looking to India and China to scale up their revenues and to access new customers.

India is disproportionately young, roughly half the population is less than 25 years of age. According to Deloitte LLP, 2010 report, India is forecasted to become the world's fifth largest consumer market by 2025 and to have 50 million outbound tourists by 2020 , providing significant opportunities for consumer businesses.

Organized retail penetration accounts for between 5 to 8 percent. The unorganized market consists of 12 million kiranas according to PWC retail report 2014. The retail and wholesale sector accounts for $14 \%$ of GDP . This sector is the second largest employer after agriculture.

The Indian retail industry is expected to increase to USD 750-850 billion by 2015 . Food and Grocery is the largest category within the retail sector with a share of $60 \%$ followed by Apparel and Mobile Segment.
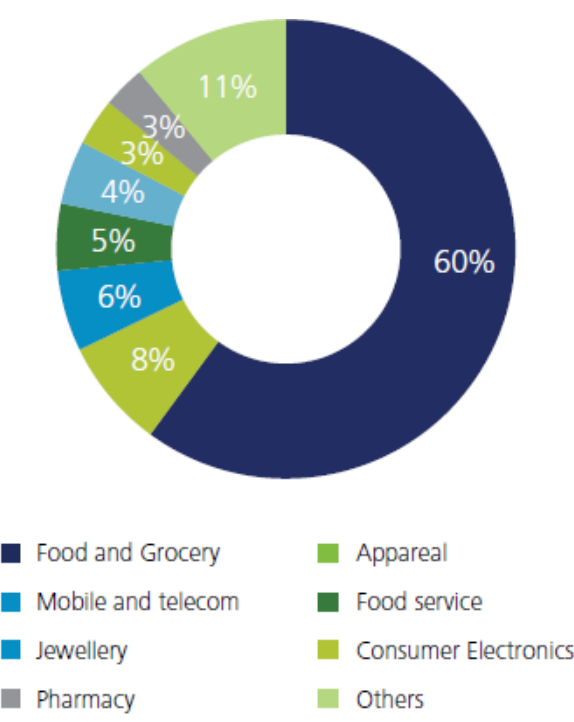

Source: India Retail Report 2013, Images Group

\section{Food retail}

According to Euromonitor, the consumer spending on food is expected to be around 895 billion USD by 2020. The time-constrained urban Indian consumer has started adopting quicker ways for preparing traditional menus. Many urban Indians pick up a pack of ready-to-use products to reduce the time spent in the kitchen. Even the traditional recipes that were manually ground at home involving multiple ingredients have changed to instant recipes and powders available in convenient pouches. Convenience and non-fussy efforts rule the kitchen.

Lifestyles are changing in proportion to the increasing spending power, constraint on time, higher need for convenience, simplifying things and health consciousness. These factors have encouraged the urban Indians to catch up with the breakfast cereals. The influence of western lifestyles and exposure to multicultural environment has influenced the eating behaviour of Indians and is opening up the gates for breakfast cereal manufacturers. The breakfast cereals market was 157 million USD in 2013 and is likely to witness a steady growth. These breakfast cereal manufacturers have introduced healthy fortified options to various categories according their age- kids category, all-family segment and for aging adults. India being a large market with growing double income households, more women entering the work force, starved of time has a great potential for the breakfast cereal market. Increasing urbanisation, health consciousness and high incidences of heart attacks, diabetes, blood pressure and high levels of cholesterol are pushing consumers to have wholesome foods. The challenges for retailers are creating product awareness, brand loyalty, understanding consumer buying behaviour etc.

\section{Exotic vegetables}

The Indian food services sector has grown rapidly, both qualitatively and quantitatively and there is an increased demand for exotic vegetables like broccoli, baby corn etc. from Italian, Mediterranean 
restaurants that have sprung up in major cities. The consumers are well educated, global trotters, have higher disposable incomes and are becoming more global. Farmers and retailers have realised the potential in this market as it provides huge returns on these products.

\section{Fashion and apparel retail}

Brick and mortar apparel and fashion retailers are increasingly facing competition not only from foreign brands but also from e-commerce space. They need to adopt different pricing strategies for casual or routine wear and for event or party wear and this is likely to be the key differentiator in this area. In-house brands will focus on setting up exclusive outlets .

\section{Jewellery retail}

There is a great shift in the consumption pattern as far as the jewellery market is concerned. The concept of jewellery as an investment has now shifted to jewellery as indulgence. There is a huge demand for light weight, trendy jewellery and designer wear. Exclusive jewellery brands will witness increasing demand from tier 1 and tier 2 cities. There is going to be heavy demand for trendy readymade jewellery as against customised jewellery and it poses a great challenge toanticipate the demand, manage the inventory and enhance visual and store display as also retaining customers.

\section{Luxury retail}

Watches and jewellery segments represent the fastest growing segments within the luxury goods sector. Watches and jewellery brands are upgrading their luxury product line for special occasions like weddings and anniversaries . Consumers are more inclined towards unique, classy pieces with intrinsic design. Taking a cue from this, domestic and international brands are luring customers with innovation in design.

According to Technopak, India luxury trends 2011-12, India has over 2 million households earning USD $1,00,000$ or more annually and these households are expected to grow at a rate of $13 \%$ over the coming years. India ranks $15^{\text {th }}$ amongst the countries having the maximum number of high net worth individuals (HNI)

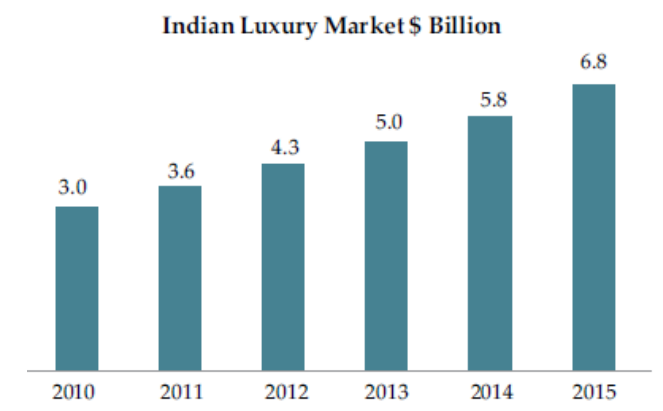

Source: Technopak India luxury trends 2011-12

Men have started preferring retail destinations that have something that offer for them like precious watches, gem-studded gadgets, accessories for men and these retail stores will be destinations for luxury retailing.

Yummies, standing for young urban males are men in their 20s with six figure salaries or more, living in cities with a taste for luxury goods, a well groomed appearance and a habit of spending on themselves. This class of consumers are the biggest consumer group for premium brands. This is driven by psychological and social trends, wherein consumers prefer to flaunt their social status. They like to experiment with their clothes and looks. Perfumes, cosmetics, shoes, outdoor sports wear and fashion accessories for men will receive a significant boost since the arrival of the yummy and these are potential areas that retailers need to focus on. Digital technology has helped in information on brands being available at the touch of a button to the target audience.

\section{Beauty and skin care products}

With people becoming more conscious of their looks and image, there is a huge demand for beauty and skin care products. Increasingly, premium beauty brands are offering additional services like skin diagnosis at their outlets to engage their customers. For the retailers, it means a long term business opportunity based on the diagnosis and better sales and service. 


\section{Private Labels}

Private labels enable retailers to offer a better price for their products as also helps retailers in getting better margins. The patronage for private labels will increase adding pressure on manufacturers' brands. Organic goods, processed foods, international foods are gaining momentum in the Indian food retailing scene.

\section{Organic goods}

As consumers become more aware of products and their contents and are more health conscious, the demand for organic products has been steadily increasing. These are areas in retail poised for steep growth.

\section{FMCG}

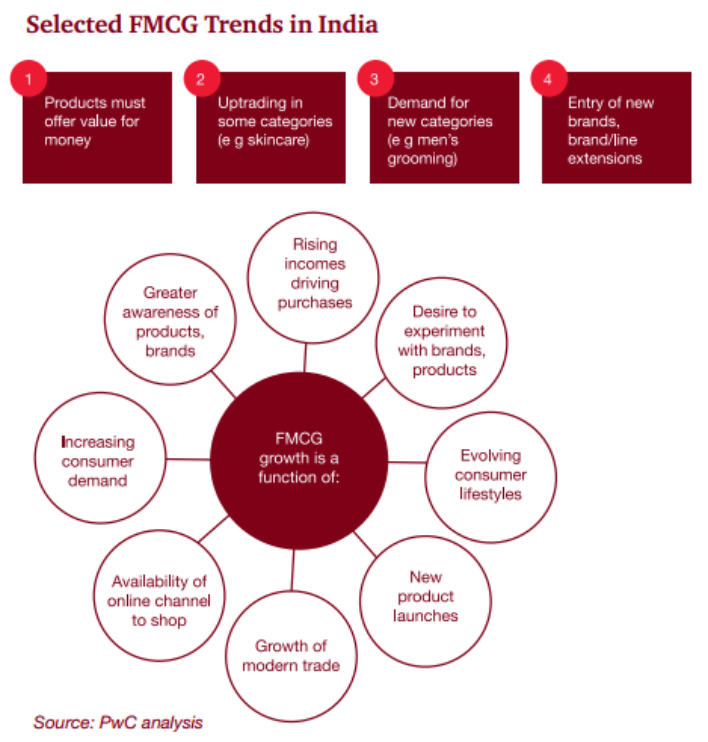

As more Indians travel abroad and are exposed to global products, their appetite to consume products in their home market is set to increase. FMCG companies will need to focus on R\&D and innovation. Consumer durables and electronics companies are launching new products and the pressure to market new products quickly is very strong. Most FMCG brands are designing and launching new products to capture the attention of Indian consumers.

\section{Key enablers or drivers of growth:}

India is one of the youngest and largest consumer markets in the world with a median age of 25.1 years, the lowest when compared to other developed countries. Their earning potential is much more when compared to their parents at that age. They add buoyancy to theeconomy through purchase of severalcategories of products like two-wheelers, four-wheelers, branded apparel, mobile phones, light weight jewellery etc.

High disposable income, late age of marriage, nuclear families, high rate of divorce, longevity, children settling abroad, exposure to multi-cultural environment, increase in women in work force are all contributors for increase in consumer spending.

On the other hand, additionally rising social costs related to health care, taxes, higher education and other areas will continue to stress disposable income. However, there is likely to be increased demand for financial services as the income earners will plan and save for retirement.

\section{Increased access to credit}

As the middle class rises, there is an increase in availability of credit. In emerging markets, banks and retailers have recognized the profitablility of lending small amounts to large numbers of low income consumers. This has resulted in increased demand for electronic gadgets, furniture and automobiles. As the sales of two and four wheelers increases, there is more mobility and freedom in choosing where to shop . This has a great potential for increase in demand for travel and leisure products and services.

\section{Aging population}


As countries are becoming more developed, single child is the norm of the day or at the most two children in each household. With children going abroad for greater opportunities and settling abroad coupled with increased life expectancy of parents, there is a huge demand for retirement communities with all amenities including shopping centres, hospitals, canteen, cab and other facilities.Higher life expectancy puts financial pressure on the working generation that must support the retired population.

\section{Urbanization}

Urban India's share in merchandise retail is expected to grow from $48 \%$ in 2012 to nearly $56 \%$ by 2021. Since the era of globalisation, India is witnessing rapid urbanisation in the past two decades. According to Technopak report 2012, there are 53 Indian cities with population in excess of 1 million. Urban consumers, who are starved of time and who have to spend a lot of time in commuting to their work places will to a great extent drive retail sales of fast and ready to eat foods. They are also likely to indulge in impulsive buying, when they will want to unwind at a mall during weekends. These are potential areas where the retailers will take the cue and lure the customers.

\section{Consumers want to simplify their life}

Source: The Futures Company, Global Monitor

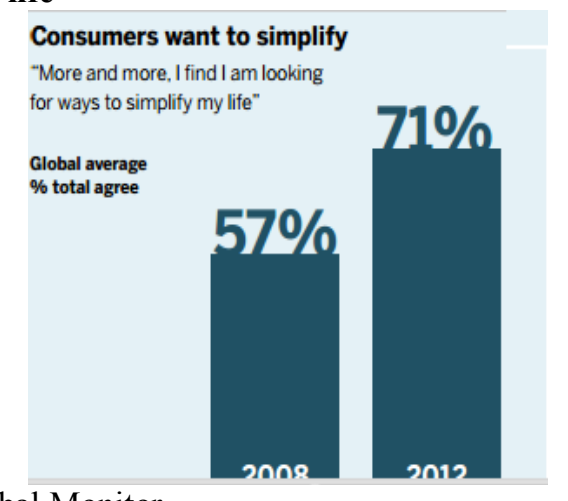

Consumers want technology to be easy to use. Consumers want devices to simplify their lives, provide entertainment and express who they are. Thus, people are looking forsimplification and ease of use. These are hints which companies have to take seriously and provide products which are convenient and easy, thus simplifying their lives.

\section{Digital Shopping}

Although the industry experts and retail sector do not expect online shopping to completely replace the brick and mortar stores, digital is making great strides with the next generation shopping. The younger generations are tech savvy and the older generations are starting to use the internet for purchase of merchandise that offer home delivery, more so in crowded cities, where crawling through the traffic is a great pain. Thus, the interest in online ordering has to be turned into a great opportunity by brick and mortar retailers.

E-tailing in India is poised to grow manifold in the years to come due to factors like internet access via broadband or through mobile networks, 4G, availability and affordability of smart phones, tech savvy customers, and a sizeable share of consumers who are deprived of time for shopping through the brick and mortar formats. On the other hand, lack of affordable real estate will become the enabler for e-tailing to grow at a fast pace in India. This will generate employment in the area of delivery of goods from the warehouse to the consumer's place, which is also termed as last mile delivery.

Of the active internet users in urban cities, 26.3 million access the web through their mobile phones. According to TCS-FICCI report on retail, up to $75 \%$ of the users of smart phones are school and college kids or young men and over $75 \%$ of the Indians visit social networking sites on their smartphones.

Thus, multichannel environment has created multichannel shoppers. This is the biggest challenge for the brick and mortar retailers. As consumers are able to compare prices across various channels before making a purchase decision, the brick and mortar retailers will have to make their presence across channels to cater to the changing needs of a multichannel consumer.

\section{Dinks}

As countries become more developed, the opportunity for women to become educated and employed increases. This has led to a new class, namely, DINKS( Double Income No Kids), which has resulted in increased demand for products - for example, Home theatres for entertainment. They also engage in weekend outings, going on vacations abroad etc. which are all opportunities for retailers to tap. 
Also, as women are increasingly focussing on their career and are time-starved, there is great demand for ready to eat foods, processed foods and meals outside the home.

\section{Growing waist line}

As purchasing power increases, people shift from grain-based diets to diets dominated by foods such as meat, dairy products, fish, fruits and vegetables(World Economic Forum and Deloitte Touche Tohmatsu, 2009). Urbanization also leads to less physically demanding work dueto use of technology, transportation and watching television for entertainment. These changes in consumer behaviour leads to obesity. According to a report in 'Times of India' dated $29^{\text {th }}$ May 2014, one in five in India is obese. India with 41 million obese people, ranks third after the US and China (Institute of Health Metrics and Evaluation).

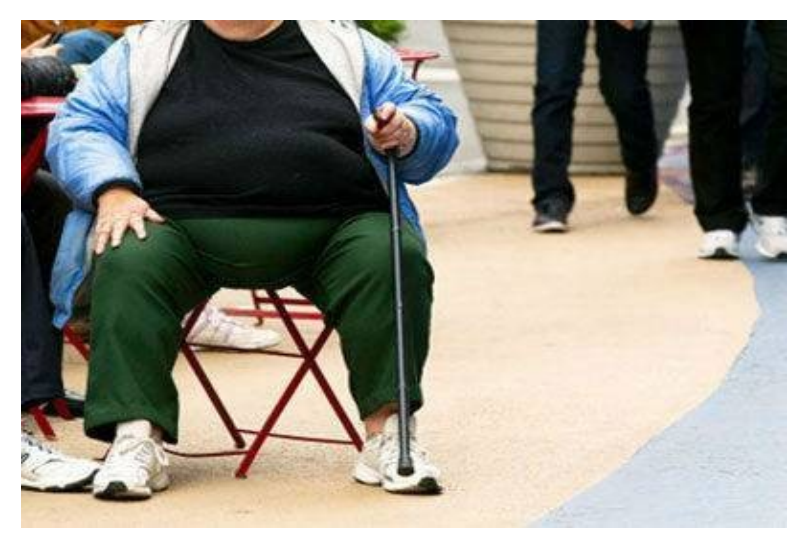

This obesity epidemic has already caught the urban middle class and has created opportunities for gym and fitness centres. Also, there is increased demand for weight management drinks and slimming capsules .As consumers are becoming more health conscious and are more educated about the need to combat obesity, there is a change in the food consumption pattern towards more fresh foods with less consumption of meat.

\section{Rising food prices}

Higher food prices will redefine consumer values. In order to make both ends meet, many consumers will be more cautious and selective in what they buy. Many will be forced to buy cheaper local products rather than imported products. It is a great challenge for the retailers. The higher prices will contribute consumers spending a major share of the total consumer expenditure on food items leaving lesser disposable income for non-food items.

As food supply chain becomes global, the risk of contamination along the supply chain rises. As consumers are more demanding than ever before, they are demanding more transparency in the origin and contents, examine food labels and are becoming more selective while making purchases.

\section{Loyalty of consumers}

The loyalty of the next generation consumers is short lived and they are greatly influenced by networks of "friends" - They are well knit - not one or two but with thousands the world over. Therefore, companies risk losing loyalty overnight if they misstep. The younger consumers create content about products, brands and service experiences. According to Qualman, 34\% of bloggers post opinions about products and brands.

\section{Changing Consumer Behavior}

The Indian consumer is changing rapidly. They have a wide range of products, quality and prices. Organised retail has changed the whole concept of shopping. Shopping in now a great experience. Retailers and marketers often seek to learn how and why people shop. The consumer decision-making process is a complex phenomenon. Consumers have access to information through a variety of sources more so, with the technology revolution. This has broadened the choice for the customers and have complicated decisionmaking.

Characteristics of eight consumer decision-making styles are:

1. Perfectionist/ high quality-conscious consumer

2. Brand consciousness

3. Novelty and fashion consciousness

4. Recreational and shopping conscious

5. Price conscious 
6. Impulsiveness

7. Confused by over choice

8. Habitual or brand loyal

According to Sproles\&Kendall(1986), identification of these characteristics among consumers helps to profile an individual consumer style, educate consumers about their specific decision making characteristics . This is a potential area, where retailers by engaging right people in store can to a great extent aid customers in decision making process. It is this area where brand promoters play a very vital role. It is needless to mention that the retailer needs to put himself in the shoes of the customer in order to serve customers beyond their expectations.

\section{Challenges for the Indian retailers}

India will surpass China to become the most populous country in the world by 2030. This puts a great pressure on the resources, products and services. The country's frequent droughts and long-standing water management problems have led to the predictions that the country could run dry by mid-century (Veeralapalam et.al , 2009)

\section{What to expect of consumers in the next decade?}

In countries with insufficient pension systems, the older population will have to continue to work and retire later in life. This will lead to savings and financial planning for future as well as health care and this would mean that they would tighten their belts and spend less on leisure services. The older generation continuing to work and retiring late in life, would alsomean more unemployment of the educated youth.

\section{Supply chain management - Logistics, cold chain and warehousing}

The retail sector is facing a major issue relating to supply chain management(SCM) . A sound SCM ensures smooth flow of goods from the producer/ manufacturer to the ultimate consumer. An efficient SCM helps in improving operational efficiency and also reduction in cost. Lack of logistics infrastructure in India is a major challenge for the retailers. Lack of adequate cold storage chains leadsto heavy wastage of marketable produce.

\section{Cutting costs and inefficiencies}

Retailers need to continuously focus their attention on reducing operating costs. In a highly competitive environment, retailers have to keep a tab on the operating costs and keep it at the barest minimum possible. Negotiations with the vendors is important to reduce the cost of procurement. Leading retailers use private labels by identifying the features consumers value most and redesign their products. Retailers should outsource support functions like finance, HR, logistics and IT so that they will be in a position to focus on core retail functions like merchandising, marketing analytics etc.

Inventory management, merchandise management, store management, financial management, people management, waste management, customer relationship management, energy management are all areas where retailers will have to focus their attention.

\section{Waste management}

According to UNEP, almost 50 percent of the world's edible crop harvest does not make it to households for consumption (United Nations, 2009). There is an urgent need to curb wastages. Consumer and regulatory pressures will require companies to put in place new manufacturing and production practices. Companies will have to look for new sources of materials, integrate supply chains, ad adopt new business models.

\section{Distribution revolution}

It is not unreasonable to think that consumers will expect same day delivery, offer delivery free of charge to their loyal customers. Companies are investing in distribution infrastructure to provide safe, secure, convenient and quick delivery. Also, third party distribution services are expected to evolve and expand in a great way.

\section{Go everywhere a consumer goes}

Companies need to be present everywhere their customers go . Prior to ICT revolution, consumers went to the store to make purchases. Today consumers use multi-channel before making a purchase. Hence, retailers need to adopt multi-channel to offer customers a great shopping experience.

\section{Real estate portfolio}


Rising cost of real estate and also rentals as well as maintenance costs, retailers will need to migrate to digital channels. A real estate rebalancing is under way as retailers reassess what should be sold through physical space.

\section{Data Analytics}

Retailers should use analytics to make offers and decisions that are targeted and localised as well as delivered in real time. Data collection andanalyzing data to understand the tastes, preferences and needs of consumers to offer customized services on one-to-one basis. Serving a heterogeneous market is the greatest challenge for the Indian retailers. Manufacturers will have to focus on new product development and innovation is the key. Retailers will have to offer more customised services on one to one basis.

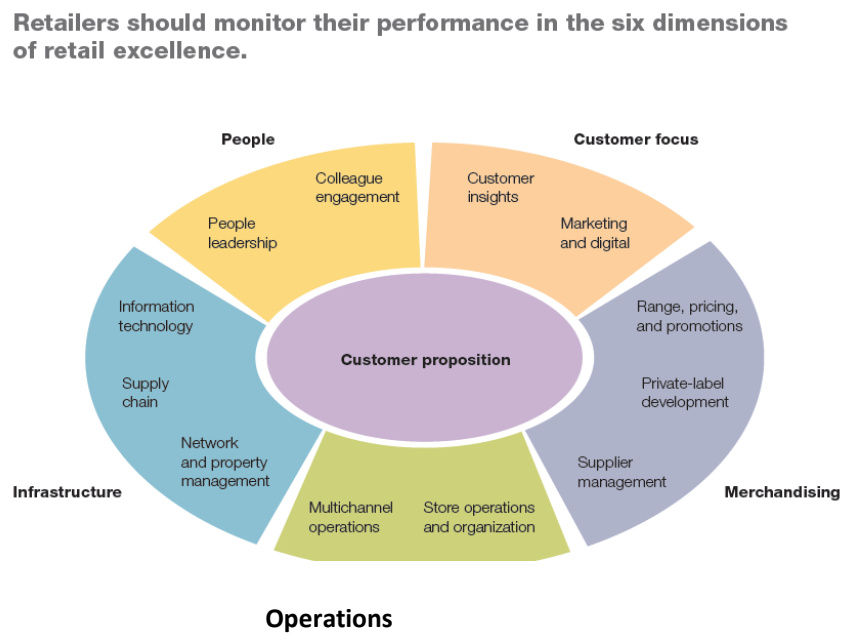

Source: In need of a retail turn around: Mckinsey\&Co( March 2014)

\section{Conclusion}

To conclude, changing demographics poses a great challenge and an ocean of opportunities for the retailers- both in the organized and in the unorganized retail. Retailers need to stay ahead of consumers and try to exceed the expectations of the consumers. They need to evolve new business models, adopt effective pricing strategies and must bring about radical changes.

The retailers need to stay ahead and satisfy the ever changing tastes and preferences of the consumers. This can be effectively implemented with the support of the Government, NGOs and through PPPs. Therole of the government cannot be undermined more so in providing level playing to the millionsin the unorganised retail and at the same time promoting the organized retail. A national levelRetail Policy, keeping in mind the interests of the various stakeholders will be an effective and an important step in this direction. This will go a long way in increasing the share of retail sector in the Indian economy. Retailers should adopt a diagnostic approach in analysing their strengths and weaknesses and keep pace with the changing times.

\section{References}

[1]. PWC-RAI report, 2010, Strategic issues for Retail CEOs: Perspectives on operating in India's retail sector.

[2]. Mckinsey\&Company report, 2008, The Great Indian Bazaar- Organised retail comes of age in India

[3]. Mckinsey\&Co. report, October 2013 - How to keep up with the consumers?

[4]. Prof.Dr. D. SudharaniRavindran et all - Study on decision making styles of Consumers in Malls www.publishingindia.com

[5]. Technopak White paper(2012)- FDI in RetailNielsen report dated 6.6.2014 - The aging population is growing, and so are its retail needs.

[6]. Deloitte report (2011) - Consumer 2020- Reading the signs

[7]. India Retail Trends (2014) - White Paper - TATA Business Support Services Limitedwww.wikiepedia.org/Demographics of India (July 2014 est.)

[8]. The Hindu- Metroplus dated $20^{\text {th }}$ June 2014- A yummy treat in the fashion world PWC report February 2013- The Indian FMCG sector- The innovation imperativeDelloite report Jan 2013- Indian retail report- Opening more doors 